\title{
Pets in airplane cabins: an unnecessary allergic hazard
}

Previously published at www.cmaj.ca

A ir travel has become increasingly difficult, with tightened security restrictions and a decreased number of services. It should not include easily avoidable health risks. But it does on some major airlines, at least for passengers with allergies to pets.

Travellers in Canada lost their access to dander-free flights in July 2009, when Air Canada reversed its prohibition against allowing small pets, including cats, dogs and birds, to travel in the airplane cabin. The apparent motivation was competition from Canada's other large airline, WestJet, which reportedly has pets on about $25 \%$ of its flights. (Service animals, whose infrequent presence on airplanes is mandated by disability considerations, are not an issue.)

It's understandable that owners prefer to keep their small pets close when travelling and that airlines are keen to compete for their business. But about 1 in 10 people have allergies to animals. ${ }^{1}$ Many will have an allergic reaction when they're trapped in an enclosed space, often for hours, close to an animal.

Severe allergic reactions, such as anaphylaxis or an exacerbation of asthma, are serious under the best of circumstances. On an airplane, at high altitude and isolated from access to emergency medical care, the consequences can be much more dangerous.

Air is filtered and exchanged more frequently and efficiently in airplane cabins than in homes or office buildings; however, the risk of exposure to allergens is not eliminated, because air circulation patterns within the cabin are hard to control. Some airlines, including Air Canada and WestJet, stopped serving peanuts following reports of anaphylactic reactions in people who had inhaled peanut dust. $^{2}$ Despite air filtration and exchange systems, transmission on airplanes of infectious diseases such as tuberculosis is well documented. ${ }^{3}$

Seating passengers with allergies away from pets is not a realistic alternative. Pet dander remains on seats long after the pet and its owner have gone. One study identified clinically relevant concentrations of cat allergen on $100 \%$ of sampled airplane seats on domestic flights and $16 \%$ of seats on international flights. ${ }^{4}$ Moreover, flights are usually filled to capacity, and airlines have not created mechanisms to facilitate lastminute seat changes.

On Jan. 7, 2010, the Canadian Transportation Agency ruled that people with allergies to nuts should be considered to have a disability under the Canada Transportation Act and must therefore be accommodated. The agency is now review- ing passenger complaints about pets on airplanes and determining whether those with allergies to pets should also be considered as having a disability.

Such a finding would force Canadian airlines to safeguard passengers with allergies to pets. If the agency does not rule for the passengers, the House of Commons Standing Committee on Health, which heard a briefing on this issue last fall, should take up the cause.

Air travel is an important and often necessary part of life and business, especially in large countries like Canada. People with allergies should be able to fly without placing their health at risk and must not be prevented from travelling for fear of being confined close to a pet.

The preferences of pet owners should not supersede the well-being of their fellow passengers. Pets can be accommodated comfortably and safely in airplane cargo holds, which is where they belong. Airlines must choose to put the needs of their human passengers first, or be forced to do so.

\section{Matthew B. Stanbrook MD PhD \\ Deputy Editor, Scientific \\ CMAJ}

Thomas Kovesi MD

Department of Pediatrics

University of Ottawa

Paul C. Hébert MD MHSc

Editor-in-Chief

CMAJ

Editorial advisory team: Ken Flegel MDCM MSc, Noni MacDonald MD MSc and Joan Ramsay BA

Competing interests: See www.cmaj.ca/misc/edboard.shtml. None declared for Thomas Kovesi.

Acknowledgement: The authors are indebted to Dr. Robert Schellenberg for providing information used in preparing this editorial.

CMAJ 2010. DOI:10.1503/cmaj.010100

\section{REFERENCES}

1. Noertjojo K, Dimich-Ward H, Obata H, et al. Exposure and sensitization to cat dander: asthma and asthma-like symptoms among adults. J Allergy Clin Immunol 1999; 103:60-5.

2. Comstock SS, DeMera R, Vega LC, et al. Allergic reactions to peanuts, tree nuts, and seeds aboard commercial airliners. Ann Allergy Asthma Immunol 2008;101: 51-6.

3. Kenyon TA, Valway SE, Ihle WW, et al. Tuberculosis risk after exposure on airplanes. N Engl J Med 1996;334:933-8.

4. Martin IR, Wickens K, Patchett K, et al. Cat allergen levels in public places in New Zealand. N Z Med J 1998;111:356-8. 